Jaspreet Kaur, Renata Jadresin Milic

\title{
Translation and Continuity of Tradition: An Ongoing \\ Dialogue in Aotearoa (New Zealand)
}

\author{
Traducción y continuidad de la tradición: Un diálogo \\ permanente en Aotearoa (Nueva Zelanda)
}

Tradução e continuidade da tradição: Um diálogo
contínuo em Aotearoa (Nova Zelândia)

Keywords $\mid$ Palabras clave | Pallaviras chave

Auckland, Māori Architecture, Sense of place, Architectural Tradition, Identity

Auckland, Arquitectura maorí, Sentido del lugar, Tradición arquitectónica, Identidad

Auckland, Arquitectura Maori, Sentido de lugar, Tradição Arquitectónica, Identidade

\begin{abstract}
Resumen | Resumo
Though short, Aotearoa/New Zealand's history is rich and holds an abundance of knowledge preserved in the form of songs, beliefs, practices, and narratives that inform this country's unique place in the world as well as the identity of its people. This paper observes that with migratory history and a heritage of colonization, the people of Aotearoa/New Zealand express three identities: indigenous, colonial and migrant, all with a claim to appropriate representation in the country's built fabric. It discusses the current state of knowledge by looking at the history and architectural tradition manifested in Auckland, the largest and fastest-growing city in Aotearoa. It adds that further research is required to understand and develop an appropriate methodology to address Auckland's growing multiculturalism, which lacks adequate expression.
\end{abstract}

Aunque breve, la historia de Aotearoa-Nueva Zelanda es rica y encierra infinidad de conocimientos preservados en forma de canciones, creencias, prácticas y narraciones que explican el lugar único de este país en el mundo, así como la identidad de su gente. Este artículo de investigación muestra que, con la historia de las migraciones y de la colonización como patrimonio, la gente de Aotearoa-Nueva Zelanda expresa tres identidades: indígena, colonial y emigrante, que reclaman una representación adecuada en el tejido urbano Se plantea un debate en torno al actual estado de los conocimientos mediante el estudio de la historia y la tradición arquitectónica, que se pone de manifiesto en la ciudad de Auckland, la ciudad más grande de Aotearoa y la que más deprisa crece. Se sostiene que hace falta seguir investigando para comprender y desarrollar una metodología adecuada para abordar el creciente multiculturalismo de Auckland, que carece de una expresión adecuada. 
Embora curta, a história de Aotearoa-Nova Zelândia é ainda assim rica, e detém uma abundância de conhecimentos preservados sob a forma de canções, crenças, práticas e narrativas que caracterizam a posição única deste país no mundo, bem como a identidade do seu povo. Este trabalho de investigação revela que, tendo como herança uma história migratória e de colonização, o povo de Aotearoa-Nova Zelândia expressa três identidades: Indígena, Colonial e Migrante, que reivindicam uma representação apropriada dentro do tecido construído. Inicia uma discussão em torno do estado actual do conhecimento, através do estudo da história e da tradição arquitectónica que se manifesta na cidade de Auckland, a cidade maior e com o crescimento mais rápido de Aotearoa. Argumenta que é necessária mais investigação para compreender e desenvolver uma metodologia apropriada na abordagem ao crescente multiculturalismo da cidade de Auckland, que carece de expressão adequada.

\section{Introduction}

This paper joins the ongoing discussion between architects and historians, both cultural ${ }^{1}$ and academic, agreeing that Auckland has since its origins possessed qualities encouraging people to gravitate toward it. As a result, it is today one of the world's most culturally diverse and dynamic cities, yet at the same time it lacks an interpretative appreciation of its rich past, perhaps because almost half of its population was born elsewhere. This picture of Auckland as a place of migrants and immigrants reflects a fascinating and dynamic past shaped by the spirit of adventure, a tradition of voyaging and narratives rooted in a multicultural reality. As Stone explains,

Twenty-first-century Auckland is a city of considerable cultural diversity. It is well to remember that although Auckland, as we know it, was a European creation, it had from its very beginning a mixture of peoples (Stone 2001: 286).

Consequently, Auckland is a "new home" for many of its citizens whose roots lie in their place(s) of origin and who lack a sense of belonging to this new place. This also means that Aucklanders are united in their migratory journeys to their new home, and have employed certain means of relating to it collectively.

With that in mind, we offer three initial observations. First, the architectural tradition of Aotearoa* New Zealand has three identities: indigenous, colonial and migrant; second, each asserts itself by manifesting its narratives; and third, all three identities have a claim to appropriate representation in its built fabric. Auckland, the fastest-growing and most diverse city in Aotearoa, is chosen as a case study. Our study aims to recognize and analyze patterns, techniques, theories, and methods used by these three identities to establish their "place" within the built fabric of the city.

This paper is divided into two sections. The first will look at Aotearoa/New Zealand's history and tradition and discuss early indigenous architectural traditions, followed by the development of Māori and colonial architecture as well as post-war architecture. The second will discuss the translation and continuity of tradition seen as manifestations of placemaking in the built environment. The continuity of tradition will be considered through traditional building, traditional craft techniques, and art.

We use Te Reo Mãori language to illustrate the importance of the tongue in the culture and tradition of Aotearoa. The richness of Te Reo goes far beyond what appears in our paper; for more on this, see the Glossary of Māori Architecture by Dr Deidre Brown, taken as a guide to translate Te Reo here.

\section{Aotearoa/New Zealand: history, tradition and architecture}

The first human contact with the islands of New Zealand seems to have been made in the mid-1200s by Oceanic people descending from a place called Hawaiki in Polynesia. They named their newfound land Aotearoa: Land of Long White Clouds, on account of the large white 
clouds they saw drifting over the landmass. The indigenous oral tradition of preserving and passing on knowledge tells us that several fleets of canoes voyaged to Aotearoa in 1200-1300 BC from Polynesia (Brown 2009: 20). These early inhabitants formed tribes with identities linked to the waka* that they navigated in. Their traditions were based on their collective knowledge, the experiences of their voyage, and their challenges and achievements. Their communal bonds were further cemented by the obstacles they faced in order to survive after landing on the shores of Aotearoa. They developed a culture of their own, initially like that of Polynesia. But it evolved with their ability to adapt to the unique geographical and ecological features of their new homeland.

\section{Early indigenous architecture}

A culture unique to Aotearoa became evident between 1500 and $1800 \mathrm{AD}$ (Brown 2009: 20). This was a response to the presence of unprecedented environmental challenges as well as the availability of new resources and building materials which shaped Māori society and subsequently its architecture. Early accounts of vernacular architecture report semi-permanent dwellings whose inhabitants often moved from one place to another in search of food (Brown 2014). These dwellings were organized in groups of approximately 10 houses, each occupied by a single family (Fig. 1).

Houses could be round, rectangular or oval. They had a wooden frame covered with reeds such as raupō (bulrush), toetoe or nikau palm leaves, and sometimes other materials such as bark. The earth floors were covered in tough flax mats, and the only furnishings were beds made of finer matting laid over fern leaves (Brown 2014).

This architecture typology relates to the Polynesian roots of Aotearoa's early architectural tradition, with an important link between the waka canoe and the whare* or fale*, as "the 'upturning' of one [is] claimed to be the origin of the other" (Brown 2009: 24). In the Samoan version of this story, the

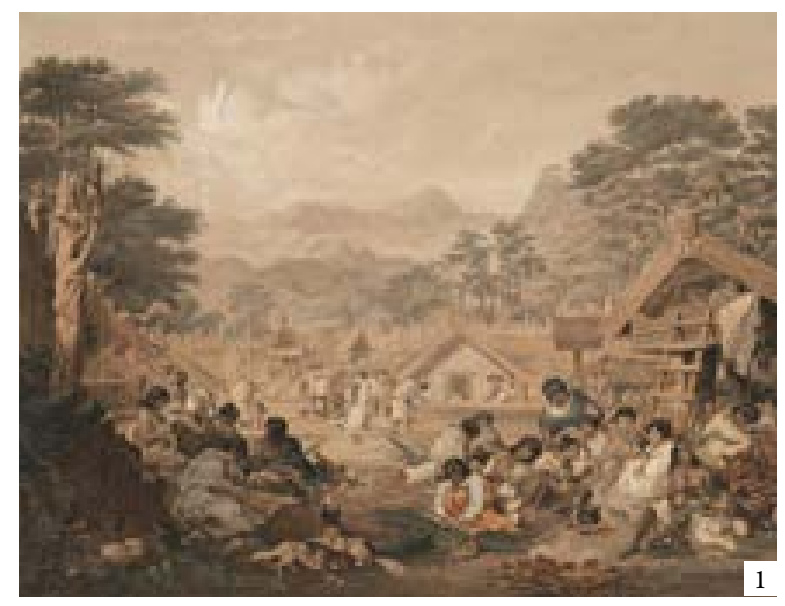

whare or fale was built first, whereas in the Tongan version, the waka came first. It was then upturned and placed on poles for use as a shelter. "The construction methods, the skills and the decorations of these two fundamental artefacts are connected and (the narrative of) water and boats affect this architecture in many ways from (its) structure to (its mechanical and spiritual) connections" (Brown 2009: 25). This connection is demonstrated by a shared tradition of ornamental carving patterns and customs associated with the construction and use of waka and whare.

In the 15th century, permanent settlements called $p a$ became prominent (Fig. 1). They occupied high ground and had trenches and fortifications to protect their inhabitants from inter-tribal warfare. $P a$ were supported by community gardens and trade as well as population growth, causing the architecture tradition to expand with new types called wharepuni* ${ }^{*}$ pataka* and katua*, which though Polynesian in origin are unique to Aotearoa (Brown 2009: 28). Wharepuni (Fig. 2), dwellings for communal sleeping, were designed as simple rectilinear structures with gable roofs extending at the front to form a porch sheltering the main entrance (Morgan-Kohu and Roberts 2003). Such porches were designed in response to Aotearoa's climatic conditions as a "moderating zone between the smoky, dark interior and the outside world" (Brown 2014). Large roof overhangs were employed to shed rainwater efficiently and shelter the walls.

A whare consisted of a framework of timber, carefully notched, and lashed together with flax, the wall spaces being filled in with screens made chiefly of kakaho, the reeds of the toetoe plant (Arundo conspicua) and the whole being covered with bundles of Rāupo (Typha angustifolia), bound on with strips of flax (Phormium tenax) (Shand 1896).

Pātaka were designed and constructed in a similar manner as rectilinear elevated structures with a gable roof and a porch, serving as communal storehouses. Pätaka are notable for having intricate carvings ornamented with inlaid pounamu* and paua*, which communicated the

Figure 1: Pūtiki pā, illustration from the Alexander Turnbull Library (Ministry for Culture and Heritage)

Figure 2: "Wharepuni, Northland" (Te Ara)

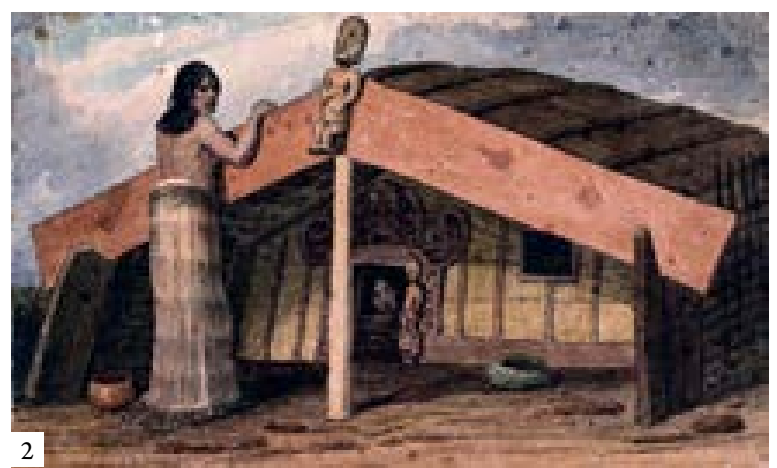


wealth and status of a tribe to neighbors and enemies (Brown 2014). Katua (Fig. 3) on the other hand, were lightframed shelters for food preparation, built using timber and lashings and lined with rāupo* and harakeke* . Construction involved many tasks divided between the men and women of the community, with men performing the heavy jobs such as preparing, dressing and transporting timber logs, carving, and thatching. Women wove the $k \bar{a} k a h o^{*}$ panels, first collecting toetoe ${ }^{*}$ and harvesting rāupo, then treating, coloring and drying the fibers.

According to historical evidence, the term Māori identifies the indigenous people of Aotearoa, though those people did not identify themselves as Māori yet. As Deidre Brown explains:

It was not until the arrival of Abel Tasman in 1642, and of subsequent explorers (...) that Māori were forced to view their society as a single body that was indigenous to this land. This was a slow process, which took around two centuries to complete (Brown 2009: 36).

Mãori was the term used by the people of Aotearoa at this point in history to identify themselves collectively and vis-àvis newcomers, whom they named Pākehā. The architecture discussed so far belongs to the Mãori. We can conclude that the first thing the people of Aotearoa inherited from their early ancestors was the tradition of voyaging, adaptability and a communal sense of place as identity. Now we transition into a new era of identity and architectural tradition, as Aotearoa begins to be known as New Zealand.

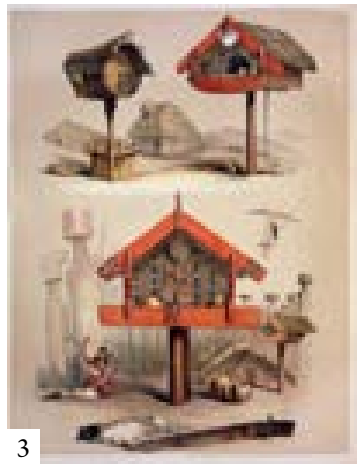

Figure 3: Illustration showing the variety of Pātaka design, "Pātaka, 1840 s”, from the Alexander Turnbull Library (Te Ara)

Figure 4: Painting showing the signing of the Treaty of Waitangi in 1840 , "Henry Williams and the Treaty of Waitangi", from the Alexander Turnbull Library (Te Ara)

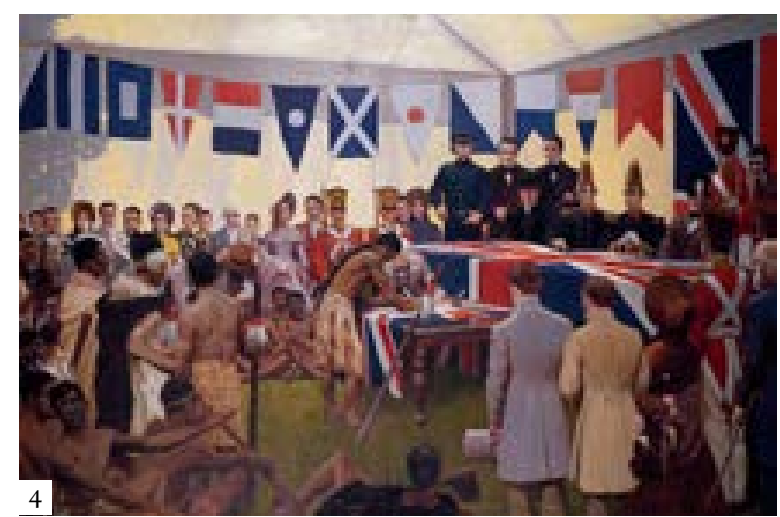

After subsequent expeditions by various European explorers, Captain Cook of Great Britain (1728-1779) ventured to Aotearoa in 1769 and again in 1773 and 1777 (NZ History 2019). The land was claimed in the name of Queen Victoria as New Zealand after the signing of the Treaty of Waitangi - New Zealand's founding document named after the place in the Bay of Islands where it was first signed on February 6, 1840 (Fig. 4). The Treaty is an agreement in Māori and English made between the British Crown and about 540 Māori rangatira*. However, the validity and purpose of this document have been a source of conflict over the years due to differences in translated meanings as well as its nonobservance by the colonial government (New Zealand Ministry for Culture and Heritage 2017). The details and use made of this treaty continue to be debated, with an ongoing dialogue over the nature of the relationship between Māori and Pākeh $\bar{a}^{2}$

Toward the end of the 18th century, the New Zealand Company began recruiting settlers in order to establish the British colony of New Zealand. The tradition of voyaging to a new land continued as migrants came to the shores of Aotearoa from Britain and its colonies in Africa, India, the Caribbean, Australia, and many allied countries. An introduction to new architectural types, styles and resources as well as social behaviors and religious beliefs brought by the British and their colonial cousins began to influence the Māori. This was a time of growth, stimulated by inspiration, availability of new resources and adaptation, but also of conflict, fueled by resistance, segregation and war. ${ }^{3}$

\section{Māori architecture}

Architecturally speaking, the diversity of thinking and resources present at this time gave rise to new architectural types in the Māori tradition: wharenui* and häkari*. The Māori combined the mana* of the pataka and the open plan of the wharepuni with an increased footprint to produce the wharenui, a flexible space used for congregational purposes such as inter-tribal meetings and large communal gatherings organized to discuss the issues of the day, such as the presence of Christianity, increasing numbers of Pākehā migrants, land sales to Pākehā, or the signing of the Treaty of Waitangi (Brown 2009: 38). Our next section relates a case study on Te Noho Kotahitanga Marae and a specific type of wharenui better known as a whare whakairo (Figs. 19 and 20). Although the terms wharenui and whare whakairo both refer to meeting houses and can be used interchangeably, there is a key difference between them:

The word whakairo means design or pattern, as well as to ornament with a design or pattern so it can be used to refer to carving, weaving, painting and tattooing... a whare whakairo is a house or a building transformed by the power of whakairo which in this case means carvings (whakairo rakau), woven panels (tukutuku) and painted patterns (kowhaiwhai) (Skinner 2016: 16). 
Figure 5: Illustration of Hākari Stage (Museum of New Zealand Te Papa Tongarewa)

Figure 6: Painting showing new settlers living in tents while their house is being erected, "Settlers under canvas", from the Alexander Turnbull Library (Te Ara)
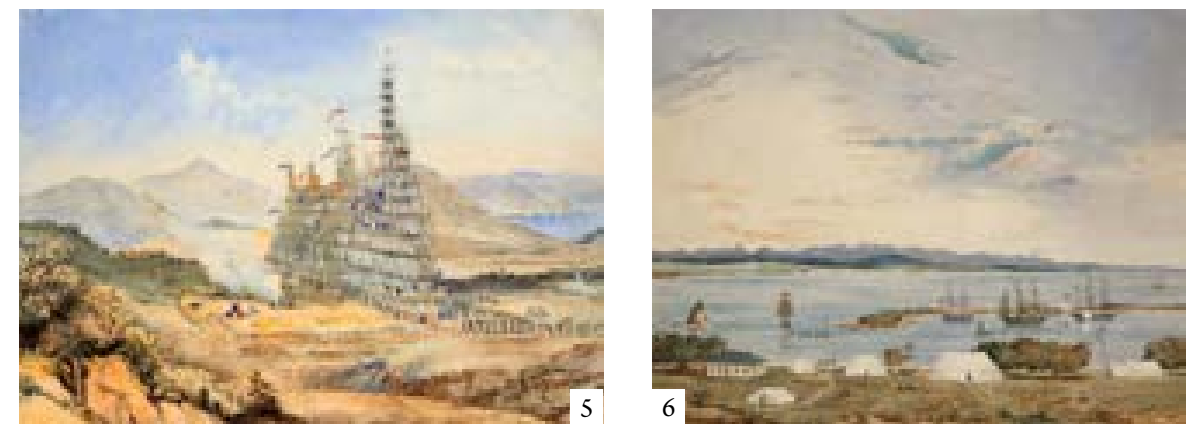

The structure of wharenui and whare whakairo is very similar to that of wharepuni, as discussed above. But the wharenui is bigger in scale, and in the case of the whare whakairo, meticulous detailing and ornamentation is involved before the building process can begin, because the carvings are structural in nature. The carving, weaving and painted patterns are not arbitrary but rather a language communicating ancestral and communal narratives.

The Māori meeting house is a particular place where Māori feel a special sense of belonging and connection to the land, their ancestors, to history and to each other (Skinner 2016: 14).

The building can be thought of as a human lying face down - the carvings on the gable at the front of the meeting house are the ancestor's face, arms and fingers; the porch is the brain, the door is the mouth and the window as the eye; carved and painted elements on the roof inside the building are the spine and the ribs, and the interior pillars in the centre of the meeting house are the heart... "this visualization of the house as an ancestor... brings together its individual members into a united organism sharing a common life and heritage" (Skinner 2016: 16-17).

Hākari feasting stages facilitated communal and inter-tribal gatherings (Fig. 5). Unfortunately, there are no surviving examples of this structural type because häkari were used only temporarily. They were post-and-lintel assemblies built with timber and flax lashings as multi-level platforms that could be conical or pyramidal in form (Brown 2009: 39). The host tribe would erect the structure to welcome their guests and showcase their wealth and prosperity, and dismantle or abandon it after use.

\section{Architecture of the 19th and 20th centuries}

As mentioned, the New Zealand Company began recruiting settlers in Britain and its colonies after the signing of the Treaty of Waitangi. But residential architecture with international origins began to be a part of Aotearoa's built fabric from the 1820-30s. Christian missionaries and government officials were among the first to arrive. Some émigrés lived temporarily in canvas tents and others were housed as guests in whare by Māori, awaiting the completion of permanent dwellings. Transportable prefabricated homes and furniture were a popular choice at this time and were available in London as early as the 1820s, designed by the firm of Henry Manning (Fig. 6).

He invented a prefabrication system whereby grooved wooden posts were slotted and bolted into a floor plate carried on bearers. The posts carried the wall plate with supporting triangulated trusses. Standardized wooden cladding panels slotted between the grooved posts. The roof, doors, glazed windows, locks and other components were all included, and each building was pre-painted inside and out (Schrader 2016: 77).

These were designed in a simple English country cottage style and featured a veranda which was later also a common element of colonial villas (Schrader 2016: 89). Prefab homes became a part of the luggage of many émigrés and were a familiar commodity in their new land. Early New Zealand towns, especially on South Island, also featured what is known as the $V$-hut: a simple gabled dwelling with a window and door at one end and a thatched or canvas roof (Schrader 2016: 86). Unfamiliarity with the New Zealand climate and perhaps also with the low thermal capacity of timber made these homes cold, draughty and unpleasant (Schrader 2016: 88). For this reason, the Māori-built rāupo houses became a preferred dwelling for settlers.

These houses were distinguished from whare by design and function. The walls were higher and featured external chimneys, small windows and hipped or gabled thatched roofs. These were hybrid dwellings, their design resembling a traditional English Cottage but built using traditional Māori materials and techniques. They cost about one-fifth the price of imported cottages and were warmer (Schrader 2016: 82-83).

The presence of the colonial cottage is still evident (Fig. 7), however, and the rāupo house has not survived due to its flammability, as demonstrated in the 1842 fire of Wellington, which consumed 57 räupo houses in 30 minutes and led to a decline of the type. In the 1860 s the villa became a prominent aspect of the townscape of $\mathrm{New}$ Zealand's emerging cities and eventually turned into the 

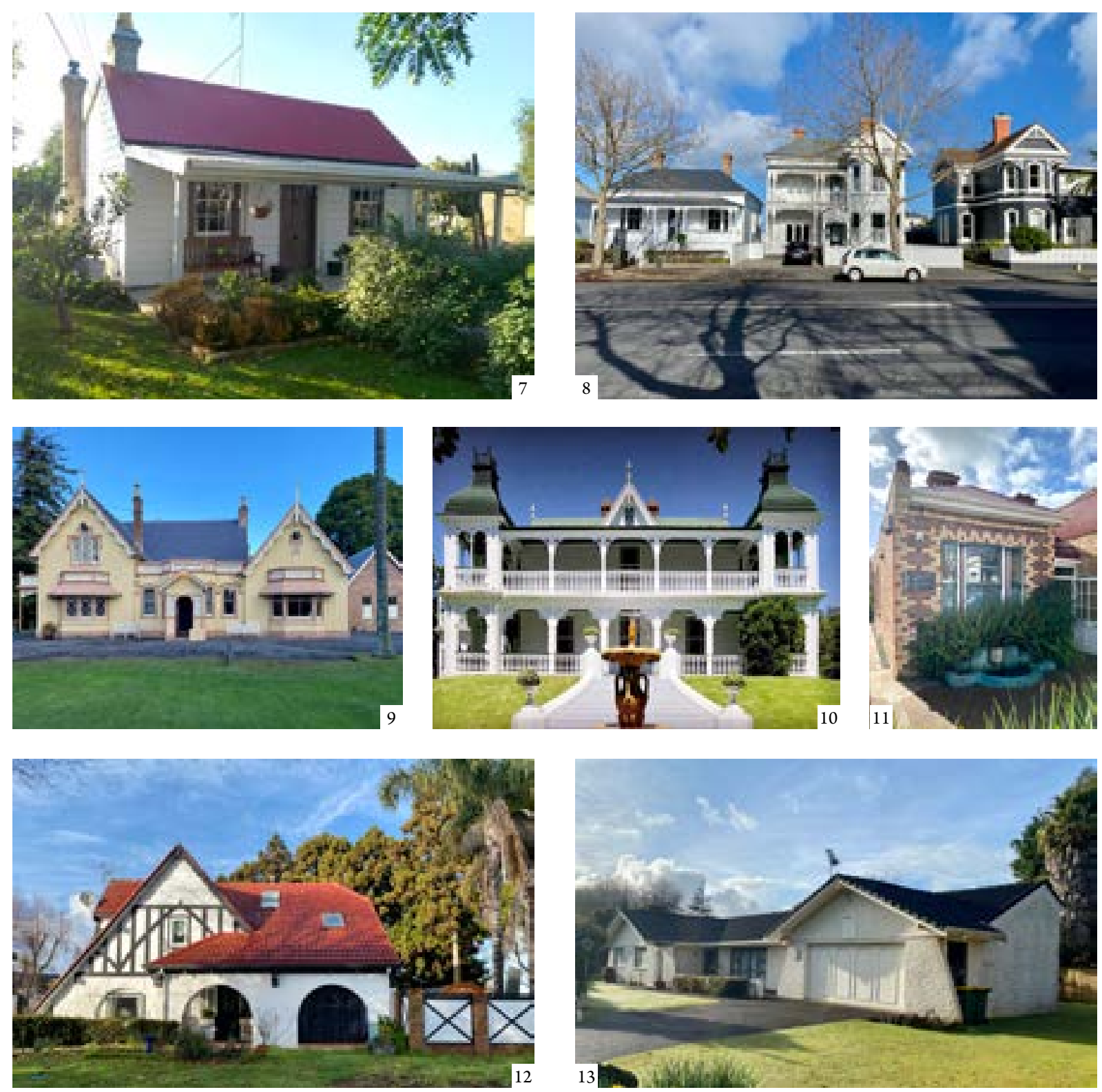

Figure 7: A surviving colonial cottage built in 1849-52 in Mangere, Auckland

Figure 8: Three adjacent villas in Freeman's Bay, Auckland, showcasing, the Georgian (left), Victorian (middle), and Neoclassical (right) styles Figure 9: Highwic Villa, in Epsom, Auckland, a surviving example of the Gothic Revival style

Figure 10: Alberton Villa in Mt. Albert, Auckland. Indian inspired verandas and turrets combined with the Victorian characteristics of the villa (Pinterest) Figure 11: Brick-faced Villa in Freeman's Bay, Auckland. Note the Neoclassical fountain and Corinthian columns between windows

Figure 12: Villa in Confer Grove, Auckland, showing a mix of styles. Note the Tudor gable front popular in Medieval Welsh and British architecture, the Gothic fringe, and the semicircular arches

Figure 13: Villa in Conifer Grove, Auckland, showing possible Spanish influences

New Zealand villa, an adaptation of the pre-existing type to the local context. Initially mere replicas of British villas, they soon began to express regional characteristics such as a smaller footprint, limited ornamentation, use of timber as a primary building material even when tradition required brick or stone (in which case the facades were aesthetically presented as stone), and the addition of a porch or veranda.

The British structures were often of grand proportion in comparison to the $N Z$ copies but possessed the same notable features including a rectangular footprint, hipped roofs with small eaves, symmetrical facades and regular windows. The NZ models usually added ground-floor verandas and had a central hallway with rooms on either side (Era Designs 2016).

A variety of architectural styles were explored at this time, including the Georgian villa (Fig. 8), the Victorian villa (Fig. 8), Renaissance revival (Figs. 8 and 11), Gothic revival (Fig. 9), Queen Anne, and the Edwardian villa. While the 
dominant colonial architecture was British in style, other national styles were also present, namely Welsh (Fig. 12), Danish, Irish, Bohemian, German, French, Spanish (Fig. 13), Indian (Fig. 10), and Chinese. Their presence contributed to the culture, economy and urban ecology of New Zealand's cities, and to the styling of villas.

The New Zealand government's involvement in expanding settlement by establishing new industry and infrastructure in the early 1900s led to the development of affordable housing for workers, better known as New Zealand state houses (McKay 2013). These can be identified as detached suburban dwellings, with a weatherboard or sometimes a brick finish, a tiled roof and standardized windows: bigger windows with three panes and smaller ones with two.

The prevailing state house style originated $[\ldots]$ from Garden City planning with the houses generally adopting an appearance derived from the English Cottage style and you can even spot a bit of the Georgian [style] in some porches (McKay 2013).

The early state house may be identified stylistically as a villa or bungalow (McKay and Stevens 2014: 14), whereas the medium-density housing and multi-story apartment blocks of the 1940s-50s show the influence of post-war émigré modernists, such as the famed Austrian architect Ernst Plischke (McKay 2013). This demonstrates the diversity and adaptability present. The initial focus was on Pākehā developments and "assimilation" of Māori in Pākehā society. This mindset did not change until the 1960 s, when an influx of Pacifica migrations and the concentration of Mãori in city centers made the government consider mainstream state housing also for Māori (McKay and Stevens 2014: 94).

The most interesting aspect of state houses is that many of them are not government housing; they just look like it. This is because other agencies such as Māori Affairs and the Education, Forestry, Police, and Public Works departments also produced affordable housing based on plans approved by the Housing Division. The government also offered cheap loans for housebuilding based on pre-approved plans (McKay and Stevens 2014: 12). Hence these houses are similar in design, construction, and materials. The state house, much like the New Zealand villa, became a familiar feature of New Zealand cities over time and is considered a part of their architectural heritage. The Lighthouse sculpture discussed in section two is an example of one.

Neoclassical style was adopted in the civic sector with enthusiasm and it remained popular well into the 20th century (Shaw and Morrison 1991: 41). The Neoclassical Auckland War Memorial Museum designed in 1929 by the practice Grierson, Aimer \& Draffin, featuring New Zealand armed forces in action during the First and Second World

Figure 14: Dilworth Building at the corner of Queen Street and Custom's Street, in Auckland. This building was designed to frame the entrance to Queen Street from the sea. A second building was never completed. (Northern Club)

Figure 15: A typical street view in the central Auckland suburbs. Note the bungalow in the foreground and its neighboring villas

Figure 16: An example of an Art déco style Villa in Mt. Albert, Auckland

Figure 17: Art déco villa in Pt. Chevalier. Weatherboard finish instead of plaster

Figure 18: Symonds Street flats designed by the Government's Housing Division as rental apartments in the 1940's, proving the arrival of Modernism in New Zealand (Te Ara)
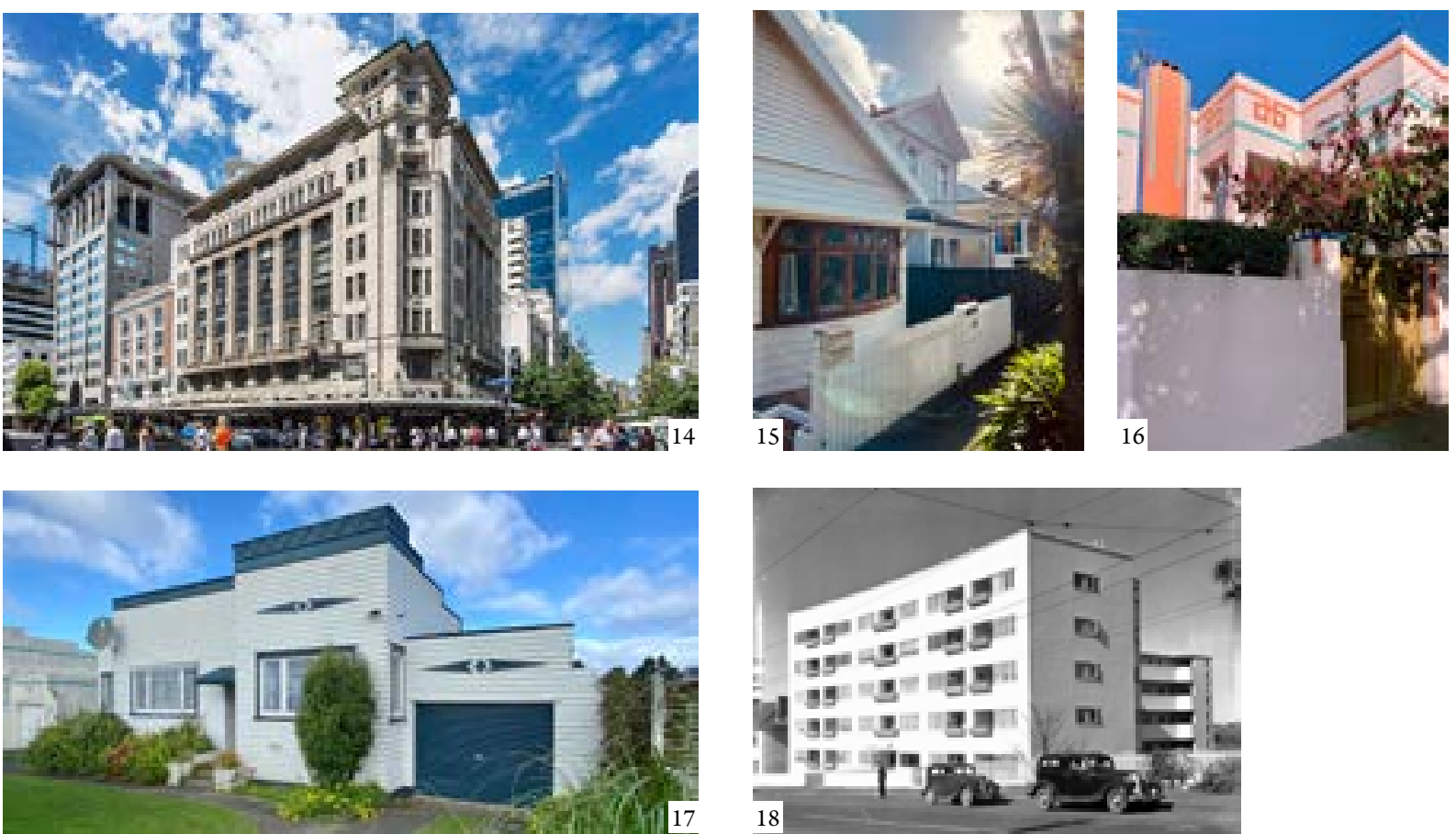
Wars in its entablature (Stevens 2015); the neo-Gothic Supreme Court designed in 1868 by Edward Rumsey with carvings of public figures on its facade including the Ngapuhi chief Hone Heke (Schrader 2021); and the Dilworth Building (Fig. 14) designed by the firm Gummer \& Ford in 1925-27 (Jones 2001), as one of two to frame the entrance to the city of Auckland, are all examples of the Neoclassical style adapted to the New Zealand context.

In the residential sector, the bungalow (Fig. 15), derived from the Hindustani bangla, became the dominant style of housing, especially in the 1920s (Era Designs 2016). It was followed by Art Deco (Figs. 16 and 17) in the 1930s, which remained popular until after the Second World War. The town of Napier has the most spectacular collection of Art Deco buildings in New Zealand. At this time, the built environment shifted rapidly from low-rise suburban to high-rise as international Modernism (Fig. 18) became dominant for commercial and institutional structures in Auckland and across the country. In post-war New Zealand a multicultural identity began to be asserted by émigrés seeking refuge here. The built environment responded to this appropriately as émigré architects, artists and designers began to explore their own respective styles, guided by Modernism, Expressionism and Brutalism, while also taking account of the natural context of their new home.

Continuity of tradition in Aotearoa/New Zealand architecture through traditional building, traditional craft techniques, and art

Much diversity of culture, technology and architectural tradition was brought to Aotearoa/New Zealand through the process of colonial settlement. Research has highlighted placemaking by continuity of tradition over the country's history, guided by key narratives of commemoration, biculturalism, diversity and connection with the natural landscape. In this section, case studies in the field of architecture, landscape design/urban environment and public art are presented as evidence of the continuity of architectural tradition in Aotearoa/New Zealand, prompted by the need for appropriate representation and a sense of identity.
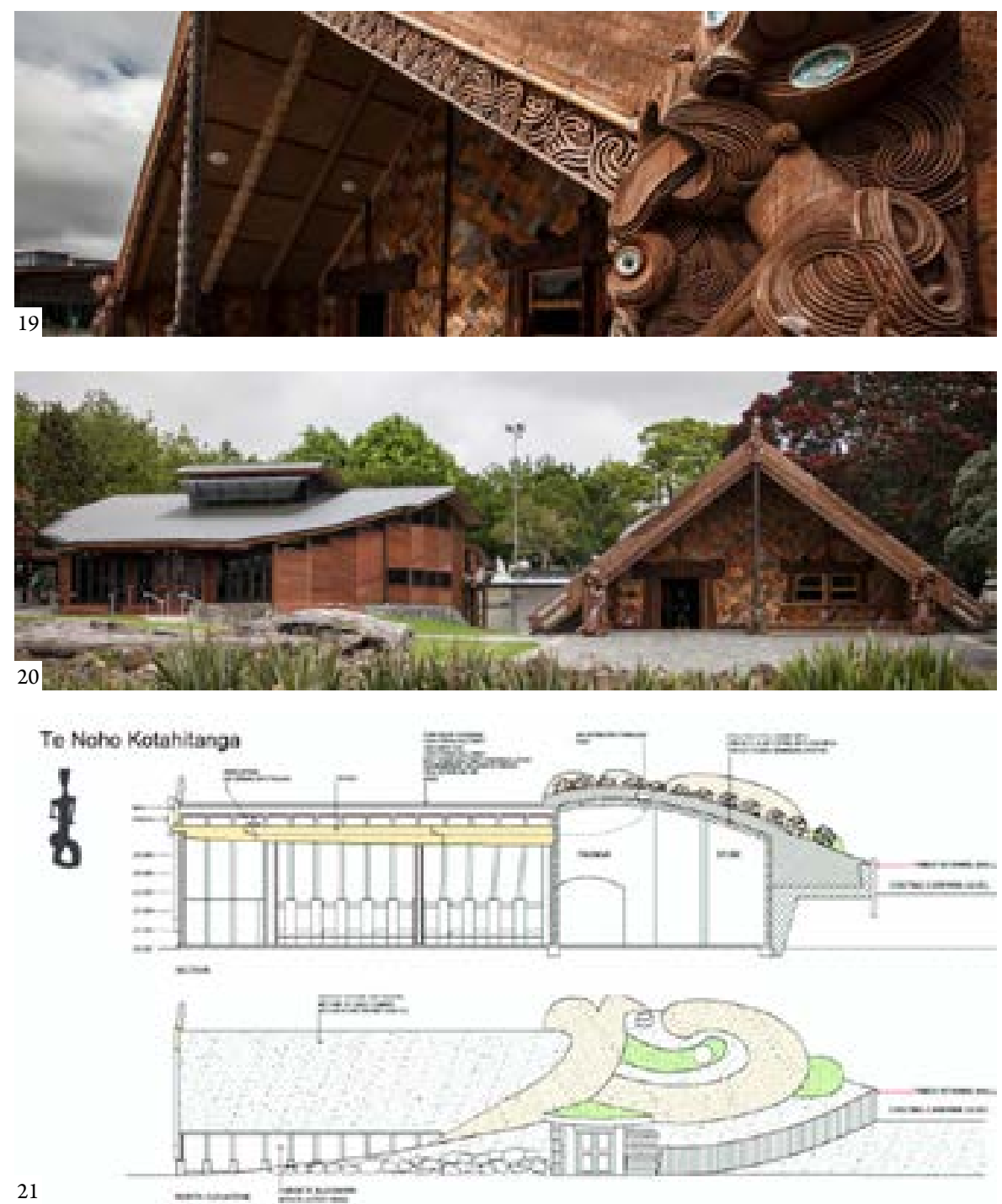

Figure 19: An example of a Whare Whakairo, “Te Noho Kotahitanga” (Unitec)

Figure 20: Pukenga (left) and Ngākau Māhaki (right), “Te Noho Kotahitanga"

Figure 21: Section and north elevation of Ngākau Māhaki, “Te Noho Kotahitanga” (Unitec) 
Traditional building: Ngākau Māhaki - Whare Whakairo of Te Noho Kotahitanga Marae, Auckland (2009), by Lyonel Grant

Our first case study concerns Ngākau Mähaki, the whare whakairo (carved meeting house) of Te Noho Kotahitanga Marae in Auckland (Fig. 19). It was opened to the public in 2009 and designed by the master carver Dr. Lyonel Grant (born in 1957) in the spirit of the traditional design ideology and building methods of Māori architecture, alongside contemporary design elements and modern technology (Unitec 2020). In Grant's work, tradition is understood as something flexible, adapting to different situations with different strategies. In his words (personal communication in 2021):

If you've had classical training, you can be so enamored with the tradition that you get subsumed by it. You end up becoming an imitator. The trick is to be an innovator because tradition is very powerful. You can easily be overwhelmed by it. A faithful copy of what the old people left isn't good enough anymore.

As mentioned, a wharenui meeting house is used for communal congregation and for this reason it is always sited at the heart of an urban complex, facing an atea - an outdoor public space. The complex is called a marae. Te Noho Kotahitanga Marae has a total of four buildings: Ngākau Māhaki, the wharenui, wharekai* maanaki, and pukenga (Fig. 20), the Māori school designed by Rewi Thomson (1953-2016) in 1993 (Brown 2017). Ngākau Māhaki is the newest addition to the complex and reinforces the Unitec Institute of Technology's commitment to the Treaty of Waitangi by ensuring a Māori presence in its research and teaching facilities.

The position of this whare results from several factors. First, it faces the rising sun. The deceased are traditionally oriented toward the rising sun on burial, and as a wharenui is seen as the living embodiment of an ancestor, most of them have this orientation (L. Grant, personal communication 2021). The whare was also set out following a careful study of the site, with its natural features, flora and adjacent buildings. Thus it faces Te Wai Unuroa or Wairaka, a natural spring revered by local Māori. According to legend, a woman named Wairaka caused the spring water to burst out of the ground on stamping her foot on the spot while complaining of thirst. Māori see water as precious because of its importance to life, and so water and watery motifs are a part of all rituals and ceremonies (Grant 2009: 4). Rewi Thompson's Pukenga features a part of the spring meandering through the interior of the building, while Ngākau Māhaki faces it.

In the original concept for the whare, the back of the building was embedded in the landscape (Fig. 21). But due to budget and time constraints and institutional pressure to complete the project, this vision was not fully realized. Yet the careful siting of the whare shows that the place and its unique features were the conceptual drivers. Grant explains how (personal communication in 2021):

When I was preparing to choose the actual site, I obtained an aerial photograph of the general site. On closer inspection there were incidental features such as clumps of manuka and shadow play (...) that suggested an entity lying prone on the site. I decided to formalize that idea and create a Manaia* form that would incorporate the adjacent structures and literally become a body occupying the land - discernible overhead if one was to use Google Earth.

It took eight years to materialize the vision of Ngākau Māhaki. Construction began by sourcing appropriate timber from a site $350 \mathrm{~km}$ south of Auckland (L. Grant, personal communication 2021). This was followed by the dressing of the timber members of the whare and then by meticulous carving. Each element is inscribed with whakairo: detailed carvings that represent selected narratives of communal identity and diversity. While traditionally Māori, the carvings tell stories about both Māori and non-Māori, thereby taking a step toward multiculturalism and creating a space for all to belong in.

I wanted to do something new, not just decorate a box, but create a showcase for our culture that's unique in the world. To do that I had to turn the clock back 100 years, look at the traditional techniques, and then work out how modern construction methods could be used to complement those techniques, given that this wharenui is maybe three times bigger than the classical model (Unitec 2019).

Not every carving and pattern can be detailed here, but we may briefly describe the back wall, central pillar and front wall. The back wall features eleven carved figures standing in front of an infinite multitude and a koru* pattern in the background. This koru is the alter ego of the takarangi that appears on the front wall, representing a swirling constellation-like presence of the heavens (L. Grant, personal communication 2021). The figures are structural elements carved in wood and the pattern on the wall is woven using flax which was then vacuum-pressed and affixed to the wall. This is aria* and the figures are ancestors of the local iwi standing in front. We see past and present sharing the same space, with the wall acting as a thin veil between us and those who came before us.

The poutokomanawa*, the central pillar, represents the signing of the Treaty of Waitangi in 1840. It is engraved with sections of the treaty and features two intertwined climbing vines symbolic of two communities coming together to create a new society (Grant and Unitec 2009). The treaty divides the whare into two parts. Narratives that took place before the treaty was signed are presented between the back wall and the poutokomanawa, and narratives taking 
place after the treaty was signed are presented between the poutokomanawa and the front wall. These narratives are communicated through the way each pou is carved and where it stands vis-à-vis the chronology.

The interior of the front wall features a carved map of Auckland showing Mt. Albert and the neighboring suburbs. A carved tahuhu* and a takarangi* on the wall is revealed as the map peels off in the center. The takarangi relates to the swirling tides of Waitemata harbor. It reminds us that our history is infused in the landscape around us. It is still evident at the present moment and if we were to simply "peel off" suburbia, this knowledge would be revealed (L. Grant, personal communication 2021).

The design and structure of this whare features a combination of traditional building techniques, hand-carvings and modern media, employed together with a post-and-lintel system and traditional lashings. It is worth noting that this whare does not use modern joinery, and that all the carved elements are structural in nature. Every pou* was carved before installation. Each one is different, representing a narrative in the story of this whare and its people. Similarly, each rafter was painted with traditional patterns before installation. The internal furnishings combine traditional woven interior panels and modern textiles. Carving and weaving patterns are a language in their own right and have been used as a means of preserving and passing on knowledge in the Māori tradition for centuries.

Crafting techniques: Kopupaka Reserve, Auckland (2016), by Isthmus Group

An example of continuity of tradition through traditional crafting techniques in Aotearoa/New Zealand today is the Kopupaka Reserve - a project making an eloquent gesture to Māori culture through design. Designed by non-Māori but with respect for Māori through engagement with them, the project is a case study using the Te Aranga Māori Design Principles. These are a set of outcome-based principles founded on intrinsic Māori cultural values and designed to provide practical guidance for enhancing outcomes for the design environment. ${ }^{4}$

Figure 22:View of Kopupaka reserve

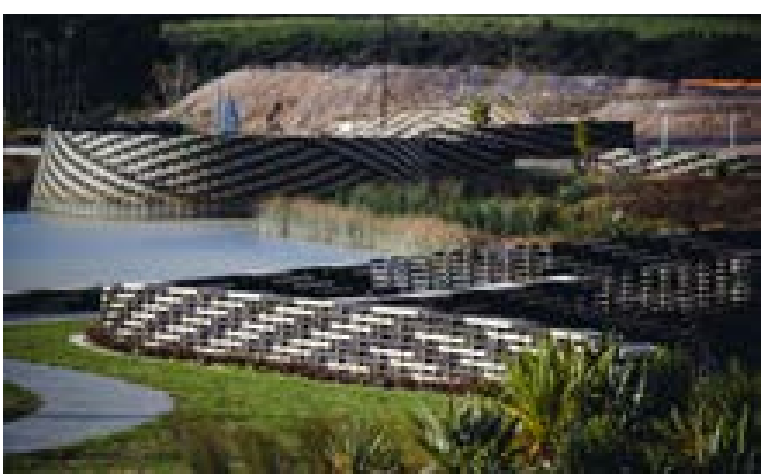

Te Aranga seeks to foster culturally appropriate responses to the built environments of Aotearoa/New Zealand, that are strongly grounded in the concepts of place and belonging intrinsic to Te Ao Māori, the Mãori world (New Zealand Institute of Landscape Architects 2016).

The Kopupaka Reserve is designed by Isthmus Group, a design studio said to be "guided by a set of principles and ideas that remove the boundaries between the disciplines of architecture, landscape and urban design, and based on deepening the relationships between land, people and culture" (Isthmus 2016). Kopupaka Reserve is a new form of a park including streams and wetlands in its design - a 22-hectare landscape made up of five stormwater wetlands (Frearson 2016). By including ecology, culture, community, and engineering in its design, it illustrates how urban growth and ecological restoration can combine to create new public space and develop a sense of place informed by Māori cultural values.

The Wetland respectfully acknowledges Māori Culture through design in translating the concept of hinaki (eel baskets), which innovatively takes on the architectural form of a river-wall system (Frearson 2016).

The overall design refers to the history of the site traditional activities and a history of food-gathering. The tradition of weaving is acknowledged and referenced, along with the architectural form of a tuna* gathering basket (Frearson 2016). A series of timber structures around the edges of three ponds create forms that weave their way across the landscape (Figs. 22 and 23). The landscape narrative subtly but evidently guides the design. The innovative use of the crib-wall system of interlocking timbers (Fig. 24) is a simple yet sophisticated design response inspired by both elements. Thus the form adopted for the structural features of Kopupaka Reserve is a creative and cultural design expression - a continuum with the past that links architectural tradition into a cohesive narrative (Auckland Design Manual 2016). Here a subtle referencing rather than an overt application of a more traditional Māori design vocabulary is used to express belonging and place, still ensuring that Māori stories are told.

Figure 23: River wall of Kopupaka reserve (Isthmus)

Figure 24 Weaving pattern of river walls constructed with timber
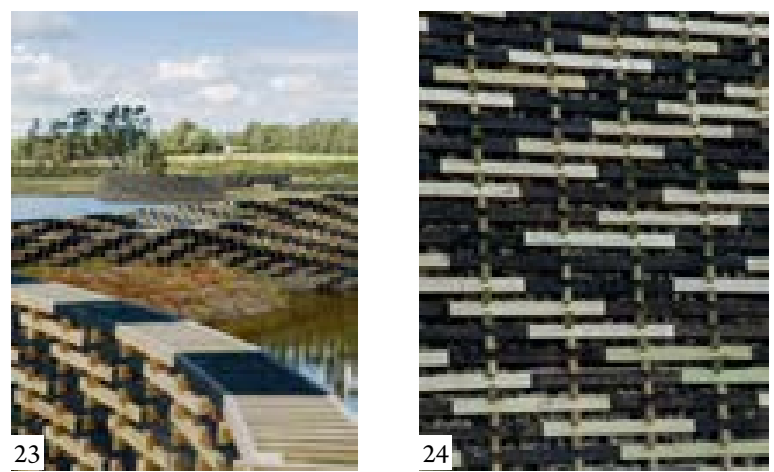


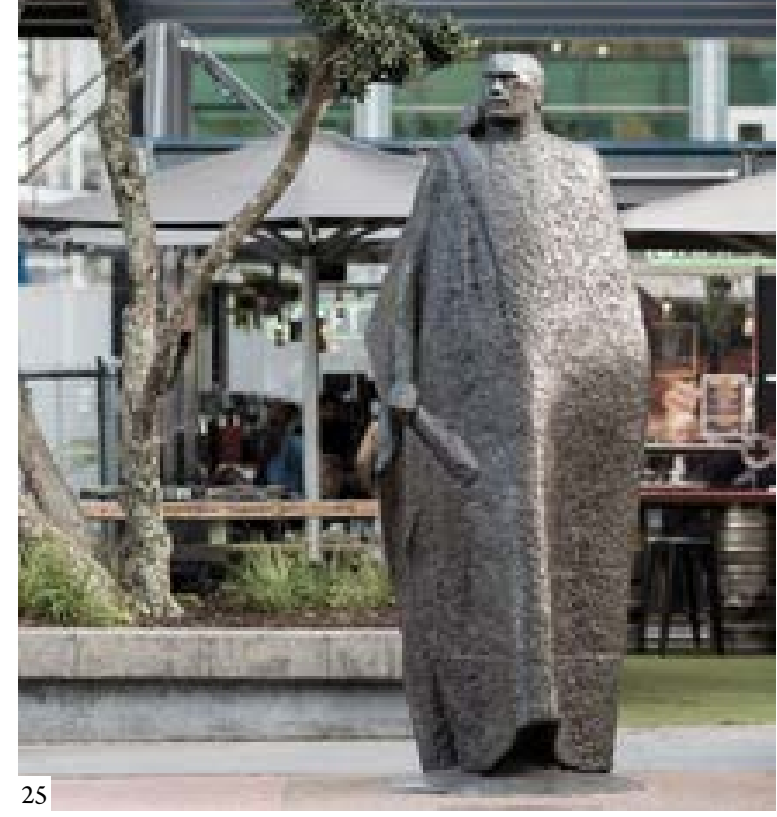

Figure 25: A Māori figure in Kaitaka cloak by Molly Macalister (Our Auckland)

Continuity of tradition: A Māori Figure in a Kaitaka Cloak (1967), by Molly Macalister, and Lighthouse (2013), by Michael Parekowhai

Research has shown that both Māori and colonial settlers began building in Aotearoa with pre-existing architectural types adapted over time to the context of their new home, in a commemoration expressed by the architecture discussed thus far. Later generations of New Zealanders growing up with exposure to both indigenous and colonial identities express appreciation for both and have produced works that promote a bicultural identity. The two artworks discussed below are examples of this growing biculturalism, redefining commemoration.

A Māori Figure in a Kaitaka Cloak, by Molly Macalister (Fig. 25), stands tall at the edge of Auckland's busiest street, opposite the Edwardian Baroque ferry terminal (Alex Wiseman 1909-1912). Macalister was commissioned to design a sculpture expected to show a Māori figure standing

Figure 26: “The Lighthouse”, by Michael Parekowhai (Pantograph Punch)

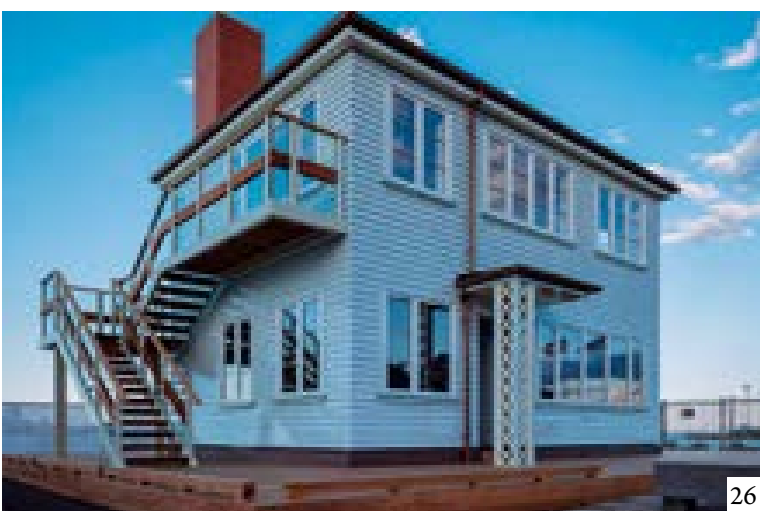

in warrior pose looking tribal and perhaps unkempt. The actual sculpture caused quite a stir, as it shows a forceful and distinguished figure, probably inspired by Apihai Te Kawau, the chief of Ngati Whatua, looking out over the city and foreshore. He wears a chiefly cloak and bears a symbol of peace (Auckland Council 2020). This was the first public artwork by a female artist portraying Māori as on a par with the British founding fathers of New Zealand. ${ }^{5}$

The Lighthouse sculpture (Fig. 26) addresses the bicultural identity of New Zealanders with a full-scale replica of a two-story 1950s-style New Zealand state house built on the Auckland waterfront (Maude 2017). Inside is a large metal sculpture of Captain Cook sitting on a chair surrounded by colorful wall-mounted neon lights (Fig. 27). As mentioned, Cook is a notable figure in Aotearoa's history, already commemorated in place names and sculptures. Contrary to his traditional heroic representation, Parekowhai presents him in a contemplative pose, caged within the house. The public see him only by peering in through the windows, as if prying into his personal space. The neon lights glowing in the interior can be seen as the explorer's train of thought as he sits alone contemplating his life, his achievements, and perhaps his regrets.

\section{Discussion of results and conclusion}

Our paper has recalled the journey that brought people to Aotearoa and shaped its architecture. As discussed, Auckland, on an isthmus between two coastlines, with an intricate network of inlets, springs, creeks, and wetlands, has many desirable qualities making it a popular location for locals and migrants alike. Its most distinctive landmark is its volcanic field with 49 discrete volcanos, and though many have been quarried, 30 remain well preserved. Studies of the early architectural tradition of Aotearoa show that Auckland began its journey on the slopes of these volcanic cones as pa sites, ${ }^{6}$ and it has continued to evolve over time with an influx of migrants.

Many years of struggle have carved the way for a bicultural national identity to be publicly accepted long after the

Figure 27: An interior view of The Lighthouse (RNZ)

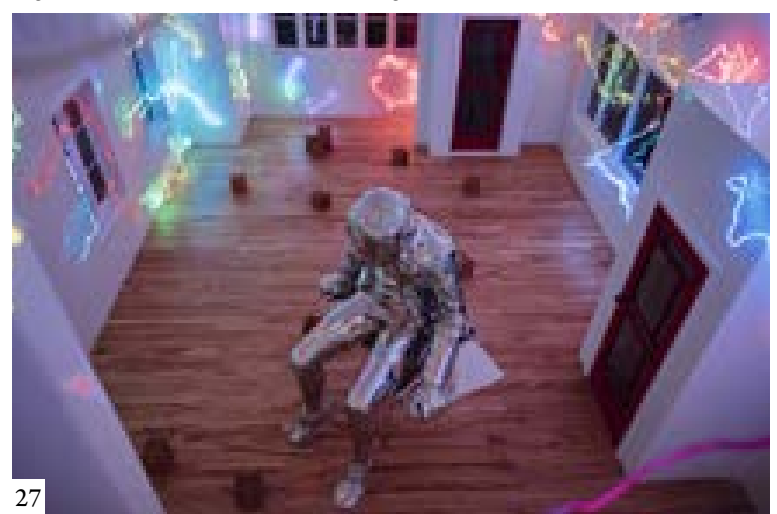


signing of the Treaty of Waitangi. Efforts are still being made to establish this bicultural identity respectfully - two equal partners having their voices equally heard, sharing power so as to empower the community, respect values, and develop strategies together. But the migrant identity of Aotearoa has yet to be addressed appropriately. In this regard, Leonard Bell's book, Strangers Arrive: Emigrés and the Arts in New Zealand, presents a collection of artistic expressions and narratives that draw attention to the struggles, stories, and contribution of migrants.

With thirty-nine percent of its population born overseas, [Auckland] city is revealed to be more diverse than Sydney, Los Angeles, London and even New York (Tan 2016).

This growing diversity results in the continually changing picture of Auckland's cultural landscape, now with roughly 180 ethnic identities (Auckland Council 2018). This demographic can be categorized in five broad ethnic groups: European (of European origin), Wider Asian (of Asian and South-Asian origin), Māori, Pacifica, and MELAA (of Middle Eastern, Latin American, and African origin). A majority of Aucklanders (59.3\%) identify as ethnically European, followed by the broad Asian category, at $23.1 \%$. The next group is Pacifica, at $14.4 \%$, followed by those identifying as Māori, at $10.7 \%$. The smallest category is MELAA, at 1.9\% (Auckland Council 2018).

Auckland is home to people from many places, cultures and traditions. This rich diversity will continue to increase (Auckland Council 2018).

The World Migration Report 2015 published by the International Organization for Migration (IOM) says that "we live in an era of unprecedented human mobility," allowing urban environments to be more ethnically diverse than before (IOM 2015). But current research shows that, though biculturalism is being explored in the architectural tradition of Aotearoa/New Zealand, an expression of multiculturalism is lacking. So the present moment requires architects, designers, and urban planners to engage with changing demographics and to represent them appropriately. Research has shown that the story of arrival is a strong narrative in the context of Aotearoa, which can be explored architecturally through historic knowledge and architectural tradition. The first part of our paper discussed Aotearoa/New Zealand's history, tradition and architecture with an overview of traditional architectural typology. Our second part looked at case studies that are potent examples of the continuity of tradition today, seen through traditional building, traditional craft techniques, and art - all providing a sense of belonging to the place that the people of Aotearoa identify with.

The case studies presented show that in Aotearoa today, the "sense of place" is based on experience and the coherence of locale, geographic features, architectural traditions, people, their customs, and personal experience. The realization of Māori identities in placemaking has great importance for Māori, ${ }^{8}$ and indeed indigenous placemaking would take up another article. Still, the ongoing dialogue allows Māori and Päkehā to connect through the sharing and presenting of traditional crafts, methods, ideas, architectural forms, and technology. The dynamic of this relationship reflects the growth of biculturalism in New Zealand. As the city continues to evolve, a sense of place including the migrant identity of Aotearoa and also the expression of multiculturalism will doubtlessly be addressed appropriately. It will continue to rely on civic art and public space to provide freedom of expression, knowledge of history, and an opportunity to discover what the future holds.

\section{Acknowledgments}

We would like to express gratitude to our colleague Maia Ratana (architect, researcher and Māori advisor), whose guidance and support were invaluable for this paper. Her thoughtful insights, factual knowledge and advice helped Māori architecture to be represented appropriately as regards its culture and values.

We are especially grateful to Dr. Lyonel Grant (Māori master carver and sculptor; Ngati Pikiao and Te Arawa) for his generosity with his time and advice, helping us to learn about Māori architecture and culture.

${ }^{1}$ The difference between cultural and academic historians: Academics are "academically" accepted and credited to have knowledge on a given subject, accessible through presentations, publications and the like. With the term "cultural historians" we include Māori elders in the conversation as specialists with extensive knowledge of the subject but who may not have any published work. Such knowledge is usually passed down within a tribe orally as lessons and techniques as well as in the form of carvings. Access to this type of knowledge can be attained by being attuned to the cultural values and traditional practices of the tribe and respectfully engaging with its elders. In recent years, we have seen a new generation of Māori who have attained knowledge from their elders and are also thriving as researchers, academics and professionals; they are accepted and credited as knowledgeable in both worlds, and through them cultural knowledge is becoming more available to the academic world.

${ }^{2}$ We refer only briefly to the Treaty of Waitangi/Te Tiriti o Waitangi, as its complexity, the subsequent land confiscations, the New Zealand land wars, and the historical atrocities endured by Māori demands a full discussion which is unfortunately beyond our scope. On this subject, see Claudia Orange, The Story of a Treaty and An Illustrated History of the Treaty of Waitangi, Bridget Williams books, Wellington, 2004 (brief historical overviews); Michael Belgrave, Merata Kawharu and David Williams (eds.), Waitangi Revisited: Perspectives on the Treaty of Waitangi, OUP, Auckland, 2005; Department of Justice, Principles for Crown Action on the Treaty of Waitangi, Wellington, 1989; I.H. Kawharu, Waitangi: Māori and Pākehā Perspectives of the Treaty of Waitangi, OUP, Auckland, 1989; Paul Moon, Te Ara Ki Te Tiriti: The Path to the Treaty of Waitangi, David Ling, Auckland, 2002; Kevin O’Brien, Rebecca Kiddle, and Luugigyoo Patrick Stewart, Our Voices: Indigeneity and Architecture, ORO Editions, 2018.

${ }^{3}$ Colonization is an ongoing issue that has impacted generations and left many feeling lost in their own country, with a story that requires another article. For more on this, see Kevin O’Brien, Rebecca Kiddle, and Luugigyoo Patrick Stewart, Our Voices: Indigeneity and Architecture, ORO Editions, 2018. For a brief information to the mid-' 80 s when 
"there was no such 'thing' as Māori architecture”, see Anthony Hoete, “Transcolonisation: 1990-2020”, Architecture Now, https:// architecturenow.co.nz/articles/transcolonisation-1990-2020/

${ }^{4}$ The purpose of this strategy is to support local $i w i$ to demonstrate cultural approaches and perspectives in terms of how to manage and build on land, and to ensure Māori culture is valued and used appropriately. See more on this in Paul, Jacqueline. Exploring Te Aranga Design Principles in Tāmaki, 2016; “Te Aranga Principles”, Auckland Design Manual. http://www.aucklanddesignmanual.co.nz/designsubjects/Maori-design/te_aranga_principles

${ }^{5}$ This is still seen as a racially insensitive event for various reasons, mainly because a Māori sculptor was not consulted.

${ }^{6}$ There are records of numerous pa sites existing in the Auckland isthmus in 1450-1840; see Bruce W. Hayward, Prehistoric Pa Sites of Metropolitan Auckland, New Zealand Geological Survey, Lower Hutt, 1983, http:// www.thebookshelf.auckland.ac.nz/docs/Tane/Tane-29/2\%20 Prehistoric\%20pa\%20sites\%20of\%20metropolitan\%20Auckland.pdf; Aileen Fox, Maungakiekie: The Mãori Pa on One Tree Hill, Auckland, New Zealand: One Tree Hill Borough Council-Domain Recreation Reserve Board, 1984.

${ }^{7}$ For more on this, see Bell, Leonard. Strangers Arrive: Émigrés and the Arts in New Zealand, 1930-1980, Auckland University Press, 2017.

${ }^{8}$ Kiddle compares the ideologies underpinning pre-colonial whannau and hapu placemaking, centered on whānau (extended family) and hapu (sub-tribe) units, with colonial placemaking, premised on the conversion of communally owned land to individual property; see Rebecca Kiddle, “Contemporary Māori placemaking” in: Kevin O’Brien, Rebecca Kiddle, and Luugigyoo Patrick Stewart, Our Voices: Indigeneity and Architecture, ORO Editions, 2018; see also Sheri-Ann Atuahiva, "What is Māori Heritage?", Māori Cultural Heritage Program, talk given in the Auckland Art Gallery Auditorium, July 28, 2021, https://www.aucklandnz.com/ business-and-investment/growing-business/networking-events/events/ public-talks-tours/what-maori.

\section{* Glossary | Glosario | Gllossário}

*As guided by the glossary of Maori architecture by Dr. Deidre Brown.

Aotearoa is the name given to the country commonly known as New Zealand, by its native people. It belongs to the Te reo language and means "the land of long white clouds". For the purpose of this paper, the authors prefer to use both names in their work because it reminds us of the shared heritage and tradition of this country and its people.

Arai is a subliminal barrier, the façade that the recently departed must navigate to enter the spirit realm. In the case of Ngakau Mahaki, the Arai is represented by the primary local iwi representatives who elegiacally stand in the path of those who desire to pass beyond.

Hākari are feasting stages.

Harakeke is a type of reed; native to Aotearoa.

Käkaho is a woven panel or screen used as an internal surface lining in whare construction; traditionally made with raupo and toetoe.

Katua is a light-framed timber structure used to define and shelter the space allocated to food preparation.

Koru is a traditional spiral pattern featured in carving and tattooing. It refers to the appearance of a new unfurling silver fern frond.

Mana is prestige.

Manaia is an ancient mythical being with a bird's head and a human form. It is said to be the messenger between the earthly world of mortals and the domain of spirits. Manaia holds great spiritual energy and is a guardian against evil. It is a popular form in carving.

Pataka is a raised and highly decorated store house.

Paua is a type of shellfish with a shiny blue-green internal shell pattern, similar to mother of pearl; native to Aotearoa.

Pou is a carved structural pillar .

Pounamu is a green semi-precious stone; native to Aotearoa.

Poutokomanawa is a central structural pillar.

Rangatira is a tribal chief.

Raupo is a type of flax; native to Aotearoa

Tahuhu is a ridge pole, symbolic of the spine of the ancestor

Takarangi is an intersecting double spiral pattern that signifies humanity's celestial origin born at the beginning of the Universe. Used widely in Maori carvings and art, the Takarangi uses space to separate it's two solid spirals; it is this space that allows us to see the spirals.

Toetoe is a type of swamp grass; native to Aotearoa.

Waka is a canoe carved out of timber .

Whare is a dwelling. Fale is the samoan variation of the word.

Wharenui is a meeting house.

Wharepuni is a rectangular, gabled dwelling designed for communal sleeping. 


\section{References $\mid$ Referencias $\mid$ Referências}

Atuahiva, Sheri-Ann. 2021. What is Māori Heritage?. Talk in Auckland Art Gallery. Mãori Cultural Heritage Programme.

Auckland Council. A Māori figure in Kaitaka cloak. https://www. aucklandcouncil.govt.nz/arts-culture-heritage/arts/public-artwaterfront/Pages/maori-figure-in-kaitiaki-cloak.aspx (consulted on 02/09/2021).

Auckland Design Manual. Kopupaka Reserve. http://www. aucklanddesignmanual.co.nz/resources/case-studies/ kopupakareserve (consulted on 15/03/2021).

Auckland Plan 2050. Auckland's Population. https://www. aucklandcouncil.govt.nz/plans-projects-policies-reports-bylaws/ our-plans-strategies/auckland-plan/about-the-auckland-plan/ Evidence\%20reports\%20documents/evidence-reportdemographics. pdf (consulted on 05/05/2019).

Bath, Brooke. 2016. Five of the best artworks in Auckland. Stuff. https:// www.stuff.co.nz/auckland/83958585/five-of-the-best-publicartworks-in-auckland (consulted on 15/09/2021).

Bell, Leonard. 2017. Strangers Arrive: Emigrés and the Arts in New Zealand, 1930-1980. Auckland: Auckland University Press.

Brown, Deidre. 2009. Māori architecture: from fale to wharenui and beyond. Auckland: Penguin Group.

Castello, Lineu. 2010. Rethinking the Meaning of Place: Conceiving Place in Architecture-urbanism. Farnham: Ethnoscapes.

Deidre Brown. 2014. Māori architecture - Whare Māori. Te Ara - The Encyclopedia of New Zealand. http://www.TeAra.govt.nz/en/Māoriarchitecture-whare-Māori (consulted on 18/03/2019).

Frearson, Amy. 2016. Kopupaka Reserve in Auckland wins World Landscape of the Year 2016. Dezeen. https://www.dezeen. com/2016/11/18/kopupaka-reserve-auckland-wins-worldlandscape-year-2016/ (consulted on 02/02/2021)

Grant, Lyonel. 2009. A Vision Beyond Its Time = Moemoeā Kei Tua i Tōnā Wā: Te Noho Kotahitanga. Auckland: Unitec New Zealand.

Grant, Lyonel. Toi Tu Toi Ora Satellite Exhibition. Auckland. https:// www.aucklandartgallery.com/toi-tu-toi-ora-satellite-exhibition (consulted on 15/03/2021).

Hochstein, Gina; and McKay, Bill. 2020. Alien Subversives. Architecture Now. Accessed March 21. https://architecturenow.co.nz/articles/ alien-subversives/ (consulted on 21/03/2021).

International Organization for Migration. 2015. World migration report 2015. Switzerland: International Organization for Migration. https:// publications.iom.int/system/files/wmr2015_en.pdf (consulted on 16/03/2021).

Isthmus. 2016. Gather and weave. Kopupaka Reserve. https://isthmus. co.nz/project/kopupaka-park/ (consulted on 08/03/2021)

Jacqueline, Paul. 2016. Exploring Te Aranga Design Principles in Tämaki. Bachelor of Landscape Architecture.

Maude, Simon. 2017. Mesmerising \$1.5m Lighthouse sculpture gets walkaround. Stuff. https://www.stuff.co.nz/life-style/89312555/ mesmerising-15m-lighthouse-sculpture-gets-walkaround (consulted 02/09/2020).

McCay, Bill. 2013. A fresh look at the state house. Architecture Now, 4 https://architecturenow.co.nz/articles/a-fresh-look-at-the-statehouse/ (consulted on 16/03/2021).

McCay, Bill; and Stevens, Andrea. 2014. Beyond the state house: New Zealand State houses from Modest to Modern. Auckland: Penguin Group.

Morgan-Kohu, Hinewirang; and Roberts, Jude. 2003. Te Whare Whakairo. Cambridge: Kina Film Productions.
New Zealand History. James Cook - biography. Ministry for Culture and Heritage. https://nzhistory.govt.nz/people/james-cook (consulted on $15 / 03 / 2015)$

O’Brien, Kevin; Kiddle, Rebecca; and Stewart, Luugigyoo Patrick. 2018 Our Voices: Indigeneity and Architecture. New York: ORO Editions.

Orum, Anthony M.; and Neal, Zachary P. (eds.). 2010. Common Ground: Readings and Reflections on Public Space. New York: Routledge.

Pollock, Kerryn. 2014. Public and street art. Te Ara - the Encyclopedia of New Zealand. https://teara.govt.nz/en/public-and-street-art (consulted on 10/09/2020).

Salmond, Jeremy. 1986. Old New Zealand Houses 1800-1940. Dunedin: Reed Methuen Publishers Ltd.

Schrader, Ben. 2016. Towns becoming cities. The Big Smoke: New Zealand cities 1840-1920. Wellington: Bridget Williams Books.

Skinner, Damian. 2016. The Māori Meeting House: Introducing the Whare Whakairo. Wellington: Te Papa.

Stone, Russell Cyril James. 2002. From Tāmaki-Makau-Rau to Auckland. Auckland: Auckland University Press.

Tan, Lincoln. 2016. Auckland more diverse than London and New York New Zealand Herald. https://www.nzherald.co.nz/nz/news/article. cfm?c id=1\&objectid=11575305 (13/06/2019)

Unitec. Marae Design. Unitec Institute of Technology. https://www. unitec.ac.nz/m\%C4\%81 ori/maia-centre-and-marae/te-nohokotahitanga-marae/marae-design (consulted on 31/03/2021)

\section{Biographies | Biografías | Biografias}

\section{Jaspreet Kaur}

Jaspreet recently earned a Master of Architecture degree from Unitec Institute of Technology in Auckland, New Zealand. She is passionate about art, architecture and history. Her research investigates architectural placemaking in Auckland in response to its growing multiculturalism. She has studied the history of Aotearoa/New Zealand, the theory of phenomenology, and the concepts of public space, collective memory, and migration with a view to understanding the importance of placemaking and its application in the built fabric. She is currently employed as a teaching assistant at Unitec. She is pursuing further study and aspires to lead an academic career.

\section{Renata Jadresin Milic}

Renata is an architect and architectural historian, Senior Lecturer at the School of Architecture, Unitec Institute of Technology, Auckland, New Zealand. Her past publications have examined Renaissance architectural history and theory; new possibilities for presenting and utilizing historic sites; and the role of architectural history and theory in architectural design and professional practice today. Renata is the author of research papers in international journals and monograph chapters and has presented at several conferences internationally. She is also a recipient of the Unitec Excellence Award 2018 for Excellence in Teaching. 